\title{
A mulher bruxa no mundo do era uma vez e a reprodução histórica da dominação sobre o gênero feminino
}

- La bruja en el mundo érase una vez y la reproducción histórica de la dominación feminina

- The witch woman in the once upon a time world and the historical reproduction of female domination

Edilane Abreu Duarte

Nancy Rita Ferreira Vieira ${ }^{2}$

Resumo: $O$ artigo em tela é parte da tese de doutoramento em andamento no Programa de Pós-graduação em Literatura e Cultura, da Universidade Federal da Bahia e traz uma abordagem acerca da personificação da mulher bruxa como a representação da metáfora do mal nos contos de fadas tradicionais. Faz-se, para tanto, uma explanação inicial acerca da vinculação da figura da mulher ao mal, especialmente na Idade Média e início da Idade Moderna, no período conhecido como o de "caça às bruxas", em que as mulheres serviram de bode expiatório às perseguições e mortes. Na construção da imagem da mulher bruxa há, então, a reprodução histórica da dominação sobre o gênero feminino. Personagem que sempre foi repugnada e segregada; imagem ne-

1 Mestrado em Literatura e Diversidade Cultural pela Universidade Estadual de Feira de Santana, Brasil. Professora Assistente da Universidade do Estado da Bahia. Doutorado em andamento em Literatura e Cultura Universidade Federal da Bahia, UFBA, Brasil. edilane_duarte@hotmail.com

2 Doutorado em Letras e Linguística pela Universidade Federal da Bahia. Professora Adjunta III da Universidade Federal da Bahia, Brasil. nancyvieira@ufba.br 
gativa que muitas vezes se perpetua sem que sejam desvelados os discursos de poder que provêm da supremacia masculina. A revisão teórica focaliza as teorias relacionadas aos estudos de gênero e de literatura infantil, perpassando pelos aspectos históricos, tais como Bruno Betelheim (1981), Judith Butler (2010), Robert Darnton (1986), Silvia Federici (2017), Michel Foucault (1996), (1999),( 2003), Guacira Louro (1997), Linda Nicholson (2000) e Scott Joan (1995), que dão subsídio à análise da reificação e perpetuação da imagem da mulher bruxa como metáfora do mal.

Palavras-chave: Bruxa. Gênero. Literatura infantil. Mulher.

Resumen: El artículo en cuestión forma parte de la tesis doctoral en curso en el Programa de Posgrado en Literatura y Cultura, de la Universidad Federal de Bahía y aporta un acercamiento sobre la personificación de la bruja como la representación de la metáfora del mal en el cuentos de hadas tradicionales. Por tanto, se hace una primera explicación sobre la conexión de la figura de la mujer con el mal, especialmente en la Edad Media y el inicio de la Edad Moderna, en el período conocido como la "caza de brujas", cuando las mujeres servían de chivo expiatorio. muerte. En la construcción de la imagen de la bruja se encuentra, entonces, la reproducción histórica de la dominación sobre el género femenino. Carácter que siempre ha estado disgustado y segregado; Imagen negativa que muchas veces se perpetúa sin desvelar los discursos de poder que provienen de la supremacía masculina. La revisión teórica se centra en las teorías relacionadas con los estudios de género y la literatura infantil, pasando por los aspectos históricos que sustentan el análisis de la cosificación y perpetuación de la imagen de la bruja como metáfora del mal.

Palabras clave: Bruja. Género. Literatura infantil. Mujeres.

Abstract: The article in question is part of the doctoral thesis in progress in the Graduate Program in Literature and Culture, at the Federal University of Bahia and brings an approach about the personification of the witch woman as the representation of the metaphor of evil in the tales of traditional fairies. Therefore, an initial explanation is made about the connection of the figure of women to evil, especially in the Middle Ages and the beginning of the Modern Age, in the period known as the "witch hunt", when women served as scapegoats. persecution and death. In the construction of the image of the witch woman, there is, then, the historical reproduction of domination over 
the female gender. Character who has always been disgusted and segregated; negative image that is often perpetuated without unveiling the discourses of power that come from male supremacy. The theoretical review focuses on theories related to gender studies and children's literature, going through the historical aspects that support the analysis of reification and perpetuation of the image of the witch woman as a metaphor for evil.

Keywords: Children's literature. Genre. Witch. Women.

No mundo do Era uma vez... da literatura infantil, deparamo-nos com um universo de fantasias, medos, conquistas e sonhos; mas, além disso, encontramos personagens que trazem à tônica da representação literária estereótipos e preconceitos que legitimam normas sociais de comportamento embasados na valorização de determinados modos de ver e viver, em detrimento daqueles que se colocam no lugar da diferença e fogem ao padrão estabelecido. É o que ocorre com a figura das bruxas, mulheres estereotipadas e condenadas por transgredirem os valores socioculturais daqueles que têm a imposição de seus discursos como única e indiscutível verdade, colocando à margem ou eliminando os que demonstram outro modo de ser e estar no tempo e no espaço.

É a partir destes aspectos que este artigo $^{3}$ versa, então, sobre a trajetória da representação da figura bruxa na literatura infantil, a partir da análise dos traços que refletem, na história da personagem, a história da mulher na sociedade pela perspectiva dos estudos de gênero. Partimos do aspecto histórico sobre a criação de um imaginário que segregou, oprimiu e matou miIhares de mulheres acusadas de praticar bruxaria, passando pelo modo como essa mentalidade foi transposta para o discurso narrativo que, por séculos, tem divulgado e legitimado a visão negativa sobre o feminino.

Para tanto, tem-se como objetivo geral apresentar o modo como as relações de gênero intervêm no processo de representação simbólica do feminino por meio da personagem bruxa nas narrativas infantis tradicionais. Fez-se necessário, para isso, analisar a maneira como a imagem da bruxa fora projetada no percurso histórico-social pós Idade Média e como isso se reflete na literatura infantil; examinar a construção do discurso que atribui a conotação negativa à bruxa, enquanto elemento feminino, nos contos de fadas tradicionais.

Tal proposição justifica-se pela necessidade de revisitar a represen-

3 É parte da tese de doutoramento, vinculada à linha de pesquisa Documentos da Memória Cultural, no Programa de Pós-Graduação em Literatura e Cultura da Universidade Federal da Bahia. 
tação da figura da mulher bruxa nos contos destinados ao público infantil, através de uma abordagem acerca das (des)continuidades na construção do imaginário acerca do estereótipo da bruxa, para que se possa apresentar o significado mais profundo da associação do feminino ao mal a partir de um discurso propositadamente construído que tem divulgado e legitimado o lugar de inferioridade atribuído à mulher. É preciso, então, apresentar uma investigação que trate das motivações que levaram à formação conflituosa da imagem da mulher bruxa, que sempre foi vista como um ser que tudo faz para prejudicar os outros e, por isso, merece ser castigada.

É importante destacar que estamos numa época em que a sociedade brasileira passa por um processo de combate ao que chamam de "ideologia de gênero"4. Apesar de todos os avanços, o século XXI é palco de um embate entre conservadores e aqueles que defendem a liberdade humana como um direito e, neste complexo processo, feministas e os movimentos LGBTQ aparecem como aqueles que têm, para os conservadores, o objetivo de destruir a família. O termo gênero tem sido motivo de discussões em instâncias oficiais como a Câmara dos Deputados, a exemplo do que ocorreu em 2014 na ocasião da aprovação do Plano Nacional de Educação - PNE ${ }^{5}$, quando, deste documento, as menções ao trabalho com gênero nas salas de aulas do país foram retiradas, sobretudo por pressão da bancada evangélica do congresso. O mesmo ocorreu com a Base Nacional Comum Curricular - BNCC ${ }^{6}$, outro documento que norteia a elaboração dos currículos escolares do país e que não prevê a discussão sobre gênero nos ambientes escolares.

A "cruzada" contra a "ideologia de gênero" se intensificou a partir do ano de 2018 com a eleição de Jair Bolsonaro à Presidência da República. Um governo declaradamente conservador e que, desde a campanha eleitoral, investiu argumentos no combate a qualquer menção ao termo gênero em sua proposta e política de governo. Uma das principais militantes do combate à "ideologia

4 Segundo Toni Reis e Edla Eggert, criou se uma falácia apelidada de "ideologia de gênero", que induziria à destruição da família "tradicional", à legalização da pedofilia, ao fim da "ordem natural" e das relações entre os gêneros, e que nega a existência da discriminação e violência contra mulheres e pessoas LGBT comprovadas com dados oficiais e estudos científicos. [...] Utilizou se também de uma espécie de terrorismo moral, atribuindo o status de demônio às pessoas favoráveis ao respeito à igualdade de gênero e diversidade sexual na educação, além de intimidar profissionais de educação com notificações extrajudiciais com ameaça de processo contra quem ousasse abordar esses assuntos na sala de aula. Criou se um movimento para "apagar" o assunto gênero do currículo escolar.

5 Em 2014, o Congresso Federal sancionou o Plano Nacional de Educação (PNE) que tem a finalidade de direcionar esforços e investimentos para a melhoria da qualidade da educação no país. Com força de lei, o PNE estabelece 20 metas a serem atingidas nos próximos 10 anos.

6 Aprovada em 2018, a Base Nacional Comum Curricular (BNCC) é um documento que regulamenta quais são as aprendizagens essenciais a serem trabalhadas nas escolas brasileiras públicas e particulares de Educação Infantil, Ensino Fundamental e Ensino Médio para garantir o direito à aprendizagem e o desenvolvimento pleno de todos os estudantes. 
de gênero" do governo de Jair Bolsonaro, além dele, por mais contraditório que possa parecer, é uma mulher, a ministra da Mulher, Família e Direitos Humanos, Damares Alves. A ministra protagonizou polêmicas como a declaração, quando de sua posse ao cargo, enfatizando que "é uma nova era no Brasil: menino veste azul e menina veste rosa" ${ }^{17}$, fazendo, metaforicamente, uma crítica às proposições dos estudos de gênero que o classificam como uma construção social e que não se baseia em imposições ligadas à biologia. Tal classificação foi proposta, por exemplo, por Joan Scott no texto Gênero, uma categoria útil de análise histórica (1995), publicado originalmente em 1986, que se tornou basilar aos estudos de gênero e o vê como uma percepção sobre as diferenças sexuais hierarquizadas em formas que constroem significados culturais dentro de um sistema de relações hierárquicas (SCOTT, 1995).

A declaração de Damares Alves também vai de encontro ao que propõe, também, Judith Butler, em sua obra Problemas de gênero: feminismo $e$ subversão da identidade (2010) publicada em 1990. Para Butler, "o gênero não deve ser meramente concebido como a inscrição cultural de significado num sexo previamente dado". (2010, p. 25). De acordo com o pensamento da autora, se assim o fosse, gênero estaria ligado à biologia numa oposição binária macho $x$ fêmea, homem $x$ mulher, masculino $x$ feminino e, neste caso, "meninos de azul e meninas de rosa", como propõe a ministra, serve como um ato que contribuí para a manutenção do que Butler chama de "ordem compulsória", em que, a repetição de gestos, signos e atos nos âmbitos sociais e culturais, reforçam a construção dos corpos masculinos e femininos.

Por levantar tais questões, Judith Butler, em sua vinda ao Brasil, em 2017, para proferir uma palestra sobre "Os fins da democracia" (no original, "The ends of democracy"), foi alvo de abaixo-assinados e protestos contra sua fala. Nestes protestos, um ato nos chamou atenção e reforçou a tese de que o imaginário acerca da figura da bruxa está diretamente ligado às questões de gênero: uma efígie de Judth Butler foi queimada em frente ao SESC Pompéia em São Paulo enquanto manifestantes gritavam "Queima a bruxa! Queima a bruxa!". Numa clara alusão às fogueiras da Inquisição, Butler foi "condenada a queimar em praça pública" por suas teorias contrariarem a ordem vigente, como ocorria com as mulheres acusadas de praticar bruxaria. Em um artigo publicado na Folha de São Paulo, a filósofa comenta o ocorrido e declara que

Talvez aqueles que queimaram uma efígie minha como bruxa e de-

7 Segundo o jornal O Globo, as imagens em que consta a declaração foram feitas na quarta-feira, 2 de janeiro de 2019, dia da cerimônia de transmissão de cargo na qual Damares assumiu a pasta. No discurso de posse, Damares já havia afirmado que "menina será princesa e menino será príncipe". Disponível em: https://oglobo.globo.com/sociedade/ menino-veste-azul-menina-veste-rosa-diz-damares-alves-em-video-23343024. Acesso em: 10 out. 2020. 
fensora dos trans não sabiam que aquelas que eram chamadas de bruxas e queimadas vivas eram mulheres cujas crenças não se enquadravam nos dogmas aceitos pela Igreja Católica. Ao longo da história, atribuíram-se às bruxas poderes que elas jamais poderiam, de fato, ter; elas viraram bodes expiatórios cuja morte deveria, supostamente, purificar a comunidade da corrupção moral e sexual. [...] O fantasma dessas mulheres como o demônio ou seus representantes encontra, hoje, eco na "diabólica" ideologia de gênero. E, no entanto, a tortura e o assassinato dessas mulheres por séculos como bruxas representaram um esforço para reprimir vozes dissidentes, aquelas que questionavam certos dogmas da religião. (BUTLER, 2017, s/p)

O imaginário acerca dos malefícios da bruxa que se instaurou no fim da Idade Média e se perpetuou ao longo dos séculos, no Brasil, ainda encontra respaldo; e, o temor às bruxas mantém-se como fator de destaque, inclusive no interior das instituições oficiais como o Ministério da Mulher, Família e Direitos Humanos em que sua ministra mais uma vez entra em cena: desta vez, conforme título de artigo publicado na Folha de São Paulo, "Damares inspira caça a bruxas e seres mágicos na literatura infantil"8. Segundo Maurício Meireles, em um vídeo que circula na internet, a ministra, faz um discurso contra diversos livros infantis, sobretudo aqueles que têm a bruxa como personagem. Um deles é o Manual Prático de Bruxaria, de Malcom Bird. Sobre ele, Damares Alves diz: "Isso é livro para dar para crianças, irmãos? Ensina como ser bruxa, como se vestir como bruxa". (apud MEIRELES, 2019, s/p). Tal posicionamento da ministra tem gerado impactos no mercado editorial e na recepção de obras com a presença de seres mágicos em suas histórias, já que editores, escritores e contadores de história, segundo o referido artigo, relatam vetos e casos de rejeição de pais e escolas a essas narrativas.

O caso mais recente a repercutir no mercado editorial foi o da Leiturinha, maior clube de assinatura voltado a livros para crianças do Brasil - um edital publicado em fevereiro dizia que o clube não aceitaria inscrições de obras que tivessem "seres mágicos, como bruxas, fadas e duendes, como temática central na história". (MElRELES, 2019, s/p)

O fato de o clube de assinaturas ter publicado o edital ${ }^{9}$ em que deixa claro que não aceitaria cadastro de histórias que tivessem a presença de seres

8 Artigo publicado na Folha de São Paulo na edição de 26 de julho 2019. Disponível em: https://www1.folha.uol. com.br/ilustrada/2019/07/bruxas-gnomos-e-seres-magicos-de-livros-infantis-entram-na-mira-de-religiosos.shtml. Acesso em: 10 out. 2020

9 Edital publicado em 04/02/2019, no qual continha a restrição de que não seriam avaliadas obras que "apresentem seres mágicos, como bruxas, fadas e duendes, como temática central na história”. Diante da polêmica gerada pelo fato, Leiturinha publicou um novo edital retirando este item dos critérios de exclusão. Novo Edital está disponível em: https://s3.amazonaws.com/cdn.leiturinha.com.br/blog/uploads/2019/02/Edital-Leiturinha-vers\%C3\%A3o-atualizada-.pdf. Acesso em: 10 out. 2020. 
mágicos como a bruxa deriva do fato de assinantes terem reclamado a respeito do envio, pelo clube de leitura, de obras que em seus enredos tinham essa personagem. Ainda segundo o Meireles (2019, s/p), "como tem um público abrangente e cresceu a ponto de hoje ter 150 mil assinantes, a Leiturinha começou a receber algumas reclamações de pais quanto a livros recebidos - alguns diziam que não queriam os filhos em contato com histórias de bruxas". Mas, não apenas o clube de leitura infantil foi alvo da "caça às bruxas", como reflexo da onda conservadora que que governa o país e que oferece respaldo a esse tipo de ação, "a Companhia das Letras tem recebido reclamações de livros sobre bruxas, em especial de colégios confessionais, mas também de alguns laicos" (MEIRELES, 2019, s/p).

Outro episódio envolvendo a proibição de venda de livros, que abrange a discussão sobre gênero, ocorreu na Bienal do livro do Rio de Janeiro em 2019. Na ocasião, o prefeito da capital carioca, Marcelo Crivella, anunciou em postagem em uma rede social a censura à História em Quadrinhos da Marvel: Vingadores - a cruzada das crianças. O motivo da censura se deve ao fato de na narrativa aparecer um beijo gay. Episódio que coincide com a repercussão do fato de a atriz Fernanda Montenegro ter aceitado um convite que, segundo ela, havia recebido e recusado, da revista Quatro cinco um para um ensaio representando as bruxas na edição especial que homenageia a literatura infantojuvenil. A atriz aparece na capa da revista da edição de outubro de 2019 vestida de bruxa, amarrada a uma fogueira de livros, fazendo alusão à censura ao conhecimento e à caça às bruxas, na legenda da foto há a frase "Salvem os livros. E as bruxas" - imagem a seguir ${ }^{10}$. Em participação no programa da Rede Globo, Encontro, apresentado por Fátima Bernardes, a atriz, comentando o caso, diz que resolveu aceitar o convite por ter havido a "coincidência de terem proibido o livro com os dois rapazes se beijando.." E finaliza dizendo, "Não se fez tão a propósito, mas já que aconteceu a conjuminação dos astros, assino embaixo. Não se pode proibir livros" (MONTENEGRO, Apud Exitoína) ${ }^{11}$.

Além destes fatos, o imaginário sobre bruxaria continua levando muIheres a sofrerem violências psicológicas e físicas, a exemplo do que aconteceu em novembro de 2019, com as mulheres indígenas das aldeias dos guarani-kaiowá, em Mato Grosso do Sul. Neste caso, segundo denúncia de uma jovem indígena em uma página do Facebook, e reportagem da Revista Fórum, evangélicos neopentecostais por quererem impor a doutrina cristã

10 A imagem também foi reproduzida num pôster de aproximadamente $34 \mathrm{x} 49 \mathrm{~cm}$ e enviada a todos os assinantes atuais da edição impressa, de todos os planos, e também a todos os leitores que assinaram a revista Quatro Cinco Um até $\mathrm{O}$ dia das bruxas (31 de outubro de 2019).

11 Fernanda Montenegro comenta foto como bruxa e é homenageada por artistas. Reportagem sem autoria disponível em: https:/exitoina.uol.com.br/noticias/tv-e-series/fernanda-montenegro-comenta-foto-como-bruxa-e-e-homenageada-por-artistas.phtml. Acesso em: 16 ago. 2020. 
aos povos tradicionais, têm torturado as mulheres, sobretudo as mais velhas, responsáveis por serem as guardiãs da cultura e da religiosidade de seu povo, sob a acusação de que elas são praticantes de bruxaria. Segundo a indígena Jaqueline Gonçalves, que fez a denúncia na rede social, exibindo inclusive vídeos dos momentos em que as mulheres recebem ameaças e são golpeadas com facão e outros instrumentos; "Os intolerantes neopentecostais as tratam como bruxas, macumbeiras, feiticeiras, demônios e tudo de ruim. Elas são marginalizadas, humilhadas e torturadas na frente de todos na comunidade." (GONÇALVES apud Revista Fórum, 2019, s/p)

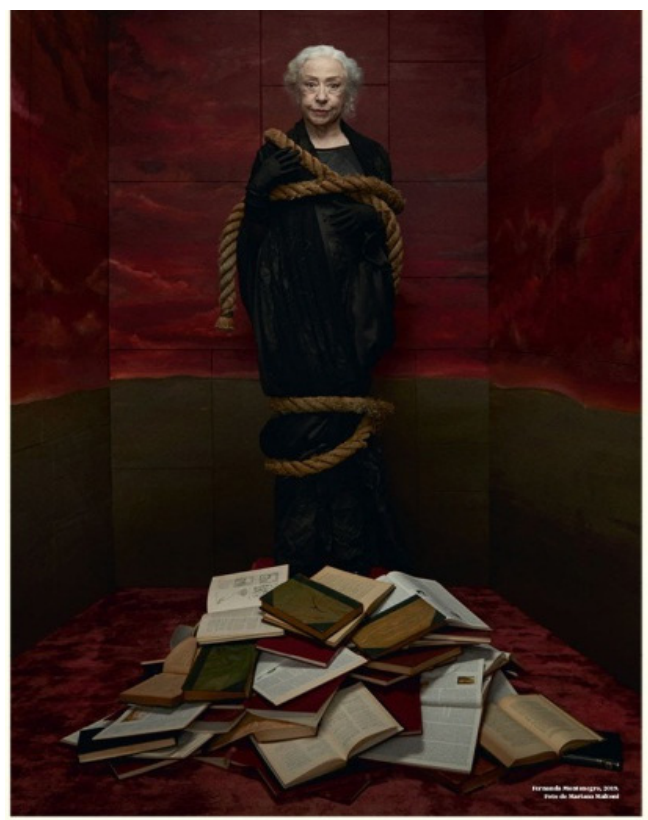

Salvem os livros. E as bruxas.

Quatro cinco um

(Foto: Mariana Maltoni, reprodução site da revista Quatro cinco um)

Além destes fatos, o imaginário sobre bruxaria continua levando muIheres a sofrerem violências psicológicas e físicas, a exemplo do que aconteceu em novembro de 2019, com as mulheres indígenas das aldeias dos guarani-kaiowá, em Mato Grosso do Sul. Neste caso, segundo denúncia de uma jovem indígena em uma página do Facebook, e reportagem da Revista Fórum ${ }^{12}$, evangélicos neopentecostais por quererem impor a doutrina cristã aos povos tradicionais, têm torturado as mulheres, sobretudo as mais velhas, responsáveis por serem as guardiãs da cultura e da religiosidade de seu povo,

12 Reportagem publicada no dia 20 de novembro de 2019. Disponível em: https://revistaforum.com.br/noticias/neopentecostais-torturam-indios-por-questoes-religiosas-no-mato-grosso-do-sul/. Acesso em: 10 out. 2020. 
sob a acusação de que elas são praticantes de bruxaria. Segundo a indígena Jaqueline Gonçalves, que fez a denúncia na rede social, exibindo inclusive vídeos dos momentos em que as mulheres recebem ameaças e são golpeadas com facão e outros instrumentos; "Os intolerantes neopentecostais as tratam como bruxas, macumbeiras, feiticeiras, demônios e tudo de ruim. Elas são marginalizadas, humilhadas e torturadas na frente de todos na comunidade." (GONÇALVES apud Revista Fórum, 2019, s/p)

Como se vê, a presença da bruxa no imaginário é, ainda, uma constante, por isso é imperioso verificar o modo como esse imaginário tem sido registrado e divulgado nas narrativas destinadas ao público infantil no Brasil. É um país que tem caminhado, em suas políticas de Estado para uma lógica religiosa fundamentalista que pretende "moralizá-lo". A partir dessa ideia, ignora a existência do feminicídio, acusa feministas de desvirtuarem as famílias, nega a possibilidade de escolha das mulheres quanto ao aborto, impede a educação sexual nas escolas, entre outras formas de misoginia, lgbtfobia e repressão social. Neste caso, ser mulher num país conservador é estar sujeita a violências das mais diversas e que são encaradas como punição aos comportamentos desviantes da norma masculina, como ocorria às bruxas. Por outro lado, devemos ter clareza de que a luta política contemporânea pela superação do feminicídio, pela integridade das mulheres que são aviltadas de várias formas no Brasil e em muitas partes do mundo são uma tentativa de superação à misoginia estruturante que constituiu as bases para a continuidade, através do tempo, da regulação do corpo, dos saberes e da liberdade da mulher.

Por se tratar de uma pesquisa bibliográfica de cunho qualitativo, o método de abordagem será dedutivo, partindo de uma situação geral da mulher no percurso histórico-social, para uma análise particular da figura da bruxa na literatura infantil. Quanto ao procedimento, far-se-á uso do método histórico-comparativo, pesquisando acontecimentos, processos e instituições do passado para verificar a sua influência na sociedade de hoje, comparando-se semelhanças e diferenças, a fim de observar o modo como as relações de gênero e poder se apresentam na construção da figura feminina como bruxa. As técnicas utilizadas serão as de análise de conteúdo e escolha do corpus priorizou a presença da personagem bruxa, sendo que as narrativas tradicionais Bela Adormecida no Bosque ([1697] 1998), de Charles Perrault, Rapunzel, Joãoe Maria e Branca de Neve ([1812] 2000), dos Irmãos Grimm e A sereiazinha ([1837] 2011), de Hans Christian Andersen, foram selecionadas para integrar parte da pesquisa por se constituírem como basilares para a construção e perpetuação, ao longo dos séculos, do imaginário sobre a bruxa. Quaisquer narrativas para crianças que se propuseram a representar a personagem têm essas como marco e modelo fundamental a ser seguido ou refutado. 
É importante mencionar que temos a cultura ocidental como base para as análises acerca de como a construção da figura da bruxa se constituiu e permanece. Tal construção se deu a partir de uma estrutura de poder, em que as relações de gênero aparecem como mola propulsora para a elaboração de um discurso potencializador de preconceitos e estereótipos ligados ao feminino. Estes, colocam a mulher num lugar de inferioridade de caráter nas mais diferentes conjunturas históricas, engendrando a segregação daquelas que, por seu comportamento desviante, se opõem à ordem estabelecida como ideal.

Não é nossa pretensão apresentar uma explicação sobre o fenômeno de caça às bruxas, resguardando o caráter de complexidade e as proporções do episódio, o entendemos, aqui, como uma consequência de diversos fatores que se afinaram e, dentre eles, estão as crenças, os discursos e as imagens constituintes de um imaginário sobre a bruxaria, agenciadas por instituições como a Igreja e acolhidas por uma população composta de sujeitos culturais capazes de produção simbólica.

Tratamos da Literatura Infantil como um documento da memória cultural, repleto de representações sociais com significações que, inseridas num contexto mais amplo, podem ser vistas como historicamente determinadas. Assim, a representação da bruxa nesta literatura é analisada a partir de um percurso diacrônico, partindo de sua origem no século XVII, num contraponto entre a literatura infantil e contexto social de produção, à luz dos estudos de gênero que, entre outros aspectos, revelam a produção e reprodução de aspectos de dominação do masculino sobre o feminino.

A abrangência das temáticas, presentes nas narrativas infantis, ultrapassa os limites da suposta "ingenuidade" atribuída aos enredos desses contos e se desloca para a formação de padrões oriundos das representações sociais e culturais, delineando, desta forma, as relações que são referências fundamentais para a constituição da identidade da criança. Contudo, há que se cuidar para que essa formação identitária não se processe na direção da perpetuação de discursos discriminatórios, uma vez que o processo de valoração do ser mulher e do ser homem é articulado a partir de condicionamentos sociais diretamente ligados à reprodução e perpetuação de estereótipos. A eles o indivíduo está submetido ao longo de sua formação, ou seja, seu contato e vivências com os referenciais culturais positivos ou negativos do ser homem e do ser mulher, engendrados pela sociedade da qual se faz parte.

A articulação de valores a partir de condicionamentos sociais é um processo continuado e geralmente muito sutil, quase imperceptível e é com ele que devemos nos preocupar. Assertiva concernente com o que diz Guacira Lopes Louro (1997) no que se refere às práticas rotineiras e comuns, os gestos e as palavras banalizados, para a autora, são, pois, os que precisam se tornar alvos 
de atenção renovada, de questionamento e, em especial, de desconfiança. A tarefa mais urgente, talvez, seja exatamente essa: desconfiar do que é tomado como "natural". Assim, as "inocentes" histórias infantis que, aparentemente, apenas contribuem de forma lúdica para a educação das crianças, às vezes estão associadas a discursos que regulam, instauram saberes, produzem verdades e disciplinam opiniões. Afirmação que nos remete ao que disse Foucault (2003), em Vigiar e Punir, ao afirmar que a disciplina "fabrica" indivíduos, ela é a técnica específica de um poder que os toma ao mesmo tempo como objetos e como instrumentos de seu exercício. Não é um poder triunfante nem soberano, é um poder modesto, desconfiado, que funciona a modo e procedimentos menores. Disciplina proveniente da dominação de uns sobre os outros. Para o mesmo autor em Microfísica do poder, "ela [a dominação] impõe obrigações e direitos; ela constitui cuidadosos procedimentos. Ela estabelece marcas, grava lembranças nas coisas e até nos corpos; ela se torna responsável pelas dívidas. Universo de regras que não é destinado a adoçar, mas ao contrário a satisfazer a violência". (FOUCAULT, 2003, p. 25).

Com isso, é preciso questionar não apenas o que cada história conta, mas, também, a maneira como as crianças dão significados e sentidos às imagens das personagens. Logo, é necessário atentar para o fato de os conteúdos das narrativas infantis estarem imbuídos de elementos que reproduzem a desigualdade entre gêneros e que apresentam o masculino como referencial. Para tanto, suscita-se uma análise crítica a fim ver além do que está explícito nas narrativas; urge que sejam "abertas as cortinas" dos implícitos, daquilo que segrega pelo não-dito, pois, conforme nos alerta Foucault (1996) em sua obra A ordem do discurso, um dos mais evidentes e familiares procedimentos de exclusão é o interdito.

No interdito de narrativas que colocam a personagem da mulher bruxa como sendo naturalmente aquela que faz maldades e merece ser punida está a reprodução de um discurso misógino, em que essas mulheres aparecem marcadamente odiadas, sendo as algozes incapazes de cometer quaisquer atos de bondade. Quando visitamos as narrativas tradicionais é comum nos depararmos com mulheres que assumem esse estereótipo. A exemplo do enredo de $A$ bela adormecida no bosque em que, inicialmente, há uma situação de equilíbrio representada pelo momento em que a rainha dá à luz a uma filha e mantém esse estado feliz até o dia de seu batizado. A quebra dessa linearidade ocorre quando o rei deixa de convidar uma das fadas do reino - mais especificamente, a mais velha.

Depois das cerimônias de batismo, os convidados voltaram para o palácio do rei, onde houve um grande banquete para as fadas. Diante de cada uma, foram postos talheres magníficos com um estojo de ouro maciço, onde havia uma colher, um garfo e uma faca de ouro fino, cravejados de diamantes e rubis. Mas, quando todos tinham tomado lugar à mesa, viu-se entrar uma velha fada que não tinha sido convidada, porque havia mais de cinquenta anos que ela não saía de sua torre, e a julgavam enfeitiçada ou morta. (PERRAULT, 1998, p. 7) 
A idade e o isolamento da fada mais velha aparecem como fatores determinantes para que ela não fosse convidada para o batizado da princesa. Mais de cinquenta anos que uma mulher vivia isolada de sua comunidade sem que ninguém tenha contato ou se saiba o que teria acontecido com a mesma, apenas "[...] a julgavam enfeitiçada ou morta." (p. 7), como se isso fosse uma consequência natural por seus atos de feitiçaria. A naturalidade com que é apresentada a ideia de sua suposta morte aparece como um indício de descaso para com a anciã ou, ainda, revela o temor que, supostamente, se tinha dela, já que "há mais de cinquenta anos ela não saía de sua torre" (p.07) e ninguém a visitava, não se tinha conhecimento de sua situação, se estava viva ou morta.

No caso da narrativa de Andersen, A sereiazinha, temos a Bruxa do Mar, que "rouba" a voz da jovem sereia. Tal bruxa era um ser que vivia nas profundezas do oceano, em local isolado e protegido pelos mais assombrosos caminhos. Ela não é, necessariamente, a antagonista da narrativa, como aquela dos Irmãos Grimm, pois, embora ela seja a responsável por preparar a poção mágica que muda o destino da Pequena Sereia, a Bruxa desta vez, é apresentada como aquela que detém o poder de realizar o sonho da jovem, ainda que lhe tire aquilo que ela tinha de melhor, a voz da sereia, mas o faz numa negociação e não à força ou sob algum encantamento. A Bruxa do mar não procura pela sereia para Ihe fazer o mal, ao contrário, embora viva sob a proteção de muitas criaturas assombrosas, a Pequena Sereia não conteve os seus ímpetos e, apaixonada por um humano e desejando ter pernas como ele ao invés de cauda de peixe, descobre que somente a bruxa é capaz de lhe fornecer uma poção mágica que lhe permitiria sair do mar e ir à busca de seu amado.

A Bruxa do mar ocupava, na comunidade marítima, um lugar de poder, pois era reconhecida como aquela que conhece segredos e realiza magias capazes de mudar a vida daqueles que têm coragem de procurá-la. Depois de desejar muito tornar-se humana, pensa em recorrer a quem sempre temeu para que pudesse buscar a solução para seu conflito. Porém, sem deixar de lado os estereótipos que constituem a figura da bruxa, Andersen delineia, em sua narrativa, sua personagem tal qual existia no imaginário coletivo: uma mulher monstruosa, capaz de realizar feitiços e poções mágicas, vivendo isolada em um local de difícil acesso. Acerca destes estereótipos, Paola Zordan (2005) afirma que

Como uma ameaça à sociedade, muitas vezes expulsa de sua aldeia, a bruxa era isolada, uma fugitiva que, cedo ou tarde, seria procurada para servir como confessora de apaixonados e intermediar os mais diversos prodígios exigidos por aqueles que se arriscavam indo atrás de seus poderes. (p. 337)

Além destas, temos a bruxa da história de João e de Maria, outra personagem que deu origem e ajudou a perpetuar o estigma da mulher Bruxa nas 
narrativas infantis. A velha dona da casa de doces da história João e Maria, também catalogada pelos irmãos Grimm. Nesta nos deparamos com uma família que enfrenta dificuldades financeiras somadas à incapacidade de um pai de proteger seus filhos, tal como aconteceu com Rapunzel, em que seu pai biológico concordou em entregar a menina à vizinha em troca de algumas hortaliças. Desta vez, o pai de João e Maria segue os conselhos da esposa e abandona os filhos na floresta à mercê da própria sorte, como se vê no trecho que segue:

\begin{abstract}
- O que vai ser de nós? Como vamos poder alimentar nossos filhos quando já não temos nós mesmos coisa alguma para comer?

- Vou dizer-te o que temos de fazer, meu marido - respondeu a muIher - Amanhã cedo levaremos seus filhos para o lugar mais espesso da floresta e acederemos uma fogueira, daremos uma fatia de pão a cada um e voltaremos para trabalha, lá os deixando sozinhos. Eles não conseguirão descobrir o caminho de volta e, assim, ficaremos livres deles. (GRIMM, 2000, p. 278)
\end{abstract}

Depois de abandonados pelo pai e pela madrasta, as duas crianças caminharam por três dias na floresta, famintos, encontraram uma casa feita de doces, começaram a comê-la. "João que estava achando o telhado muito gostoso, arrancou um grande pedaço dele, enquanto Maria arrancava uma vidraça inteira e sentava-se para saboreá-la à vontade". (GRIMM, 2000, p. 284). Certamente, ao ver a casa sendo destruída, a velha senhora logo quis saber o que ocorria e flagrou os irmãos degustando sua moradia. A velha senhora acolhe as crianças e logo se prepara para devorar João, enquanto coloca Maria para realizar as tarefas domésticas.

A acusação de devorar crianças era umas das mais comuns que recaía sobre as bruxas na Idade Média. Em versões de camponeses franceses, anteriores à narrativa publicada pelos irmãos Grimm, segundo Robert Darnton (1988, p. 2), ao invés de bruxa, há a presença de ogros, criaturas lendárias que fazem parte dos contos populares e - entre outras características - têm o hábito de devorar seres humanos, sobretudo crianças. Supomos, neste caso, que em razão dos acontecimentos provenientes do fenômeno da "caça às bruxas" e de todo o imaginário existente em torno da personificação do mal por intermédio das mulheres, na história de João e Maria os ogros foram substituídos por uma velha senhora, a dona da casa de doces construída com o propósito de atrair crianças a fim de devorá-las. Ora, se todos os males eram atribuídos à bruxaria, torna-se conveniente fazer a substituição da figura, também imaginária, do ogro, por a de uma bruxa. Neste caso, há uma combinação do fato de a velha ter tentado devorar o menino João, como os simbolismos associados às mulheres acusadas de bruxaria que estavam em voga à época. Entre esses simbolismos está o de serem responsáveis pela morte de crianças e também de devorá-las ou utilizá-las em rituais de magia, como afirma Federici (2017, p. 324): 
Também na imaginação popular, a bruxa começou a ser associada à imagem de uma velha luxuriosa, hostil à vida nova, que se alimentava de carne infantil ou usava os corpos das crianças para fazer suas poções mágicas - um estereótipo que, mais tarde, seria popularizado pelos livros infantis.

As madrastas também são constantemente vinculadas à figura da bruxa má, como ocorre na narrativa de Branca de Neve, catalogada, também, pelos irmãos Grimm. Nela, a Rainha, madrasta da princesa de mesmo nome da narrativa, "Tinha um espelho encantado, diante do qual ficava se contemplando horas seguidas e perguntava: - Dize $\neg$ a pura verdade, dize, espelho meu: Há no mundo mulher mais bela do que eu?" (GRIMM, 2000, p. 358), ao ouvir a resposta de que a enteada seria mais bela, "a rainha ficou lívida de raiva e de inveja. E, desde aquele momento, odiou Branca de Neve" (p. 358). Desta vez, não temos uma velha camponesa que vivia isolada na floresta, ou uma velha senhora que cultivava ervas em seu quintal. Agora nos deparamos com uma rainha, alguém que pertencia à nobreza e que, por ser "altiva e orgulhosa", não suportou saber que Branca de Neve era a mais bela do reino.

Na narrativa a rainha não é nomeada como bruxa, porém, há passagens que descrevem em seu comportamento atitudes tipicamente vinculadas às mulheres que eram acusadas de prática de bruxaria. Certamente, por este motivo ela é classificada como a bruxa da história, já que seus atos a personificam como tal. Além das maldades praticadas contra a enteada, depõem contra ela o fato de possuir em seu castelo um "aposento secreto, de aspecto sinistro" e de conhecer a localização da casa dos anões onde se escondia Branca de Neve "graças à sua arte diabólica" (GRIMM, 2000, p. 364), ao ver a enteada caída ao chão após morder a maçã envenenada, "olhou-a com o ódio ainda refletido nos olhos e dobrou uma gargalhada satânica". (p. 364) a vinculação das atitudes da rainha com a arte diabólica a coloca no patamar daquelas que, sendo mulheres, são as presas fáceis do Demônio e, portanto, potencialmente bruxas.

Outra bruxa que pactua com a representação do mesmo estereótipo é a vizinha de Rapunzel que, depois de tirá-la de seus pais biológicos, tranca a menina numa torre. No conto, catalogado pelos irmãos Grimm, temos a caracterização típica de uma mulher denominada Bruxa. Já no início da história nos deparamos com a presença de duas características que eram determinantes para que uma acusação de bruxaria recaísse sob uma mulher: o isolamento social e o cultivo de ervas. O narrador apresenta-nos um casal que tem como vizinha uma mulher proprietária de um "esplêndido jardim", que podia ser visto, através de uma janelinha, conforme podemos ver no trecho que segue:

Na casa em que morava o casal havia no fundo uma janelinha, da qual podia-se ver um esplêndido jardim repleto de das mais belas flores e folhagens. Era, porém, cercado por um muro muito alto e 
ninguém se atrevia a entrar nele, pois pertencia a uma feiticeira que tinha grandes poderes mágicos e era temida por todo mundo.

Certo dia, a mulher estava contemplando o jardim da Bruxa, através da janelinha, quando avistou um canteiro de belos rapúncios, tão verdinhos e parecendo tão frescos, que ela, que gostava muito daquela verdura, sentiu vontade de comê-la. (GRIMM, 2000, p. 322)

Narrativas que fazem parte do acervo cultural da humanidade e, ao longo dos séculos, têm sido responsáveis pela difusão de ideias e imagens acerca de suas personagens, demonstrando, com isso, o poder de permanência e perpetuação, na literatura infantil, de temas como este tratado aqui, sobretudo em razão do modo como afeta o leitor, deixando marcas que são diluídas em modos de ser e de estar no mundo ou, tão somente, guardadas na memória.

Consagradas como clássicas por um público específico, a criança, a literatura infantil tem sua base no imaginário que, ao tomar forma, se transforma em narrativas folclóricas míticas ou lendárias e suas raízes mais profundas advém dos arquétipos ${ }^{13}$ presentes no inconsciente coletivo da humanidade.

Assim, enquanto, em sua face mais visível, as histórias voltadas para a criança assumem características locais, do tempo e do país em que foram geradas, em suas motivações mais profundas elas deitam raízes no terreno fecundo e misterioso dos arquétipos. (SILVA, 2009, p. 54).

Vinculando-se a uma base arquetípica comum, as narrativas infantis respondem aos anseios, às dúvidas, às angústias e inseguranças de crianças de qualquer lugar do mundo e a qualquer época, já que os conflitos existenciais humanos são atemporais e provocam a busca incessante por respostas e soluções, tocando no que há de mais íntimo do ser humano. A atemporalidade do "era uma vez" e do "felizes para sempre" colocam os contos num lugar fora do tempo cronológico que conhecemos e os tornam passiveis de identificação em qualquer época em que sejam lidos, apresentando ao leitor modelos de comportamento a serem seguidos ou rejeitados.

Por isso, se faz necessário um olhar sob essas narrativas, já que aparecem como modelos figurativos daquilo que se deve compreender como o Bem e o Mal. Os enredos separam os vencedores e os perdedores: naturalmente, 0 "Bem" sempre vence e, ao Mal, devem ser aplicados os mais rigorosos e cruéis castigos. Essa demarcação de fronteiras separando o Bem e o Mal tem por consequência as definições, em igual proporção, tanto do prêmio concedido ao herói quanto do castigo atribuído ao vilão. Ainda que haja excessos na aplicação dos castigos, a exemplo da morte das bruxas, a mente infantil entende-os como administração da Justiça. Para o psicanalista Bruno Bettelheim (1980, p. 16),

13 Utilizamos aqui a ideia de G. Jung que empregou o termo arquétipo para designar os simbolismos nos padrões de personalidade e comportamento que se repetem e são compartilhados por toda a humanidade. 


\begin{abstract}
A convicção de que o crime não compensa é um meio de intimidação muito mais efetivo, e esta é a razão pela qual nas estórias de fadas a pessoa má sempre perde. Não é o fato de a virtude vencer no final que promove a moralidade, mas de o herói ser mais atraente para a criança, que se identifica com ele em todas as suas lutas. [...] A criança faz tais identificações por conta própria, e as lutas interiores e exteriores do herói imprimem moralidade sobre elas
\end{abstract}

A identificação é, naturalmente, com o herói e a criança regozija-se quando ele triunfa, não se importando com o modo como seus algozes são punidos. Há uma projeção e uma rejeição e, neste caso, a última recai sobre a mulher bruxa a quem Ihe foi atribuído, desde os julgamentos na Inquisição século XIII ao século XIX - à sua transposição para a arte literária, a imagem de vilã. Há, portanto, uma construção de sentido por meio da representação que institui valor positivo ou negativo à imagem da mulher. As narrativas infantis produzem saberes e ensinam formas de comportamento, além de construírem ou reforçarem significados, imbricados nas relações de poder, que organizam e regulam as práticas sociais e as condutas.

Carregando, então, as marcas da herança simbólica da "Idade das Trevas", as narrativas infantis, principalmente as tradicionais que, embora sua origem date de era anterior à cristã, seus símbolos e ideologias moralizadoras serviram aos ditames daqueles que determinavam os valores morais a serem perseguidos. Narrativas organizaram-se em torno de interdições ou permissões que estruturavam a sociedade, num arcabouço de censuras sociais, expressas de forma simbólica, com a religião como instrumento moralizador, didático e sentencioso. Neste processo, as relações de gênero, engendradas sob a égide das relações de poder, emergem por meio das práticas punitivas, tendo a mulher bruxa como passível de castigo. Suas ações passaram a ser vistas como maléficas e danosas à sociedade, revelando, assim, comportamentos sociais que destacam o lugar de superioridade, que deve ser ocupado por homens, e o de inferioridade, que deve ser ocupado por mulheres.

Os homens aparecem como sujeitos que exercem autoridade sobre a mulher, num exercício de poder como direito adquirido e regulamentado pela forma com que a sociedade se organizava e ainda se organiza. Com corpos e vidas assujeitadas, as mulheres sofreram, e ainda sofrem, com o a violência utilizada como uma técnica disciplinar que gera efeitos individuais e coletivos, já que, em muitas sociedades, a violência contra a mulher é aceita e praticada como um artefato da cultura. Para Foucault (1999), esse exercício de poder se dá em duas esferas, da técnica e da tecnologia, a saber:

Uma técnica que é centrada no corpo, produz efeitos individualizantes, manipula o corpo como foco de forças que é preciso tornar úteis e dóceis ao mesmo tempo. E, de outro lado, temos uma tecnologia que, por sua vez, é centrada não no corpo, mas na vida; uma tecnologia 
A presença da bruxa nas narrativas infantis nos ajuda a contar a história dessas mulheres e nos dá pistas que nos permitem entender as origens de muitas crenças e valores, de muitas práticas sociais frequentemente opressivas e de inúmeras formas de desclassificação e estigmatização feminina. É importante destacar que, para as bruxas, o preço de pertencer, com algum destaque, à história da humanidade foi a morte. Essas mulheres tornaram-se agentes históricos a partir do sacrifício de suas vidas e, por muito, tiveram sua história distorcida e contada a partir do ponto de vista de seus algozes, os homens.

Como dito antes, não há data precisa para a origem das narrativas que advêm da tradição oral, mas, se considerarmos as datas a partir dos registros feitos no século XVII, temos, então, mais de 400 anos de perpetuação de valores morais com ideais de bondade e maldade, sendo a maldade atribuída à mulher bruxa e ratificada ao longo dos anos. Tais narrativas fazem parte do acervo de documentos da memória cultural da humanidade e perpetuam, no inconsciente coletivo, a supremacia do masculino sobre o feminino. Há, por meio delas, a imposição de papeis e atitudes tradicionalmente aceitos como corretos ou incorretos, sendo o último ocupado pela mulher bruxa e forjado pelo poder patriarcal e sexista. Fato decorrente de uma estrutura dominante - e masculina - que encontrou nas acusações de prática de maldade através da bruxaria, um caminho para segregar, amedrontar e exterminar mulheres que ameaçavam os lugares de poder ocupados pelos homens. Tornando o fenômeno de caça às bruxas um episódio formatado e desenvolvido com bases nas relações de gênero. Aqui, entende-se gênero em consonância com o que afirma Linda Nicholson (2000, p. 1), quando assevera este é usado em oposição ao sexo para descrever o que é socialmente construído em oposição ao que é dado pela biologia. Deste modo, o gênero é pensado como referência à personalidade e comportamento e não ao corpo; Nos contos de fadas tradicionais, encontramos a figura da bruxa como uma personagem mítica tecida em tais narrativas e, por conseguinte, no imaginário, como a representante das incoerências no comportamento social. Eram consideradas perigosas e a elas eram atribuídos todos os excessos.

Deste modo, contos que atravessam gerações são responsáveis, também, pelo estabelecimento de paradigmas e estereótipos projetados no tempo e no espaço, criando esquemas interpretativos reducentes acerca da representação da mulher, no caso em tela, da mulher bruxa. Havendo, portanto, uma construção e legitimação de uma ordem simbólica que dá um significado subjacente à realidade e coloca a mulher num lugar de inferioridade ou de inversão de atribuições, normas e valores sociais, levando o leitor a conceber uma autorização, também simbólica, à aplicação de castigos àquelas que desvirtuam a ordem pré-estabelecida. 


\section{Referências}

ANDERSEN, Hans Christian. Contos de Hans Christian Andersen. Trad. Silva Duarte. São Paulo: Paulinas, 2011.

BETELHEIM, Bruno. A psicanálise dos contos de fadas. 6. ed. São Paulo: Ática, 1981.

BUTLER, Judith. Problemas de gênero: feminismo e subversão da identidade. Trad. Renato Aguiar. 3. ed. Rio de Janeiro: Civilização Brasileira, 2010.

BUTLER, Judth. Judith Butler escreve sobre sua teoria de gênero e o ataque sofrido no Brasil. Folha de São Paulo. Trad. Clara Allain. Edição de 19 de nov. 2017. Disponível em: https://www1.folha.uol.com.br/ ilustrissima/2017/11/1936103-judith-butler-escreve-sobre-o-fantasma-dogenero-e-o-ataque-sofrido-no-brasil.shtml. Acesso em: 16 de nov. 2017.

DARNTON, Robert. O grande massacre de galos, e outros episódios da história cultural francesa. Trad. Sonia Coutinho. Rio de janeiro: Graal, 1986.

FEDERICl, Silvia. Calibã e a bruxa: mulheres, corpo e acumulação primitiva. Trad. Coletivo Sycorax. São Paulo: Elefante, 2017.

FOUCAULT, Michel. A ordem do discurso: aula inaugural no College d'e France, pronunciada em 2 de dezembro de 1970. Trad. Laura Fraga de Almeida Sampaio. São Paulo: Edições Loyola, 1996.

FOUCAULT. Michel. Em defesa da sociedade: curso no College de France (1975-1976). São Paulo: Martins Fontes, 1999.

FOUCAULT, Michel. Microfísica do poder. 18. ed. Rio de Janeiro: Edições Graal, 2003.

GRIMM, Jacob GRIMM Wilhelm. Contos de fadas: obra completa. Trad. David Jardim Júnior. Rio de Janeiro: Editora Itatiaia, 2000.

GONÇALVES, Jaqueline. Neopentecostais torturam índios por questões religiosas no Mato Grosso do Sul: mulheres são chamadas de bruxas e feiticeiras por grupo recém-convertido. Revista Fórum, 2019, s/p. Disponível em: https://revistaforum.com.br/noticias/neopentecostais-torturam-indiospor-questoes-religiosas-no-mato-grosso-do-sul/. Acesso em: 5 out. 2020. 
LOURO, Guacira Lopes. Gênero, sexualidade e educação: uma perspectiva pósestruturalista. Petrópolis: Vozes, 1997.

MEIRELES, Maurício. Damares inspira caça a bruxas e seres mágicos na literatura infantil. Folha de São Paulo. Edição de 26 de julho de 2019. Disponível em: https://www1.folha.uol.com.br/ilustrada/2019/07/bruxasgnomos-e-seres-magicos-de-livros-infantis-entram-na-mira-de-religiosos. shtml. Acesso em: 10 ago. 2019.

NICHOLSON, Linda. Interpretando o Gênero. Estudos feministas, ano 8, n. 2, p. 09-41, 2000. Disponível em: https://periodicos.ufsc.br/index.php/ref/issue/ view/31. Acesso em: 25 mai. 2021.

PERRAULT, Charles. Contos de Charles Perrault: A bela adormecida no bosque. Tradução Fernanda Lopes de Almeida. São Paulo: Ática, 1998.

REIS, Toni; EGGERT, Edla. Ideologia de gênero: uma falácia construída sobre os planos de educação brasileiros. Educ. Soc., Campinas, v. 38, n. 138, p. 9-26, jan.-mar, 2017. Disponível em: http://www.scielo.br/pdf/es/v38n138/16784626-es-38-138-00009.pdf. Acesso em: 11 out. 2020.

SCOTT, Joan W. Gênero: uma categoria útil de análise histórica. Educação \& Realidade. Porto Alegre, v. 20, n. 2, jul./dez., p. 71-99, 1995.

SILVA, Vera Maria Tiezmann. Literatura infantil brasileira: um guia para professores e promotores de leitura. 2. ed. Goiânia: Cânone Editorial, 2009.

ZORDAN, Paola Basso M. B. Gomes. Bruxas: figuras de poder. Revista Estudos Feministas, Rio de Janeiro (RFRJ), v. 13, n. 2, maio-agosto, p. 331-341, 2005. Disponível em: https://periodicos.ufsc.br/index.php/ref/article/view/S0104026X200500020007/7827. Acesso em: 14 set. 2019.

Recebido em: 3 de fevereiro de 2021.

Aprovado em 27 de maio de 2021. 
